\title{
O ATIVISMO DAS ESTRELAS E A COMUNICAÇÃO DISSIDENTE
}

\author{
The activism of celebrities and dissident communication \\ El actvismo de las celebridades y comunicación inconformista \\ Jacques Alkalai Waiberg \\ Professor do Programa de Pós-Graduação em Comunicação da PUCRS \\ jacqalwa@pucrs.br
}

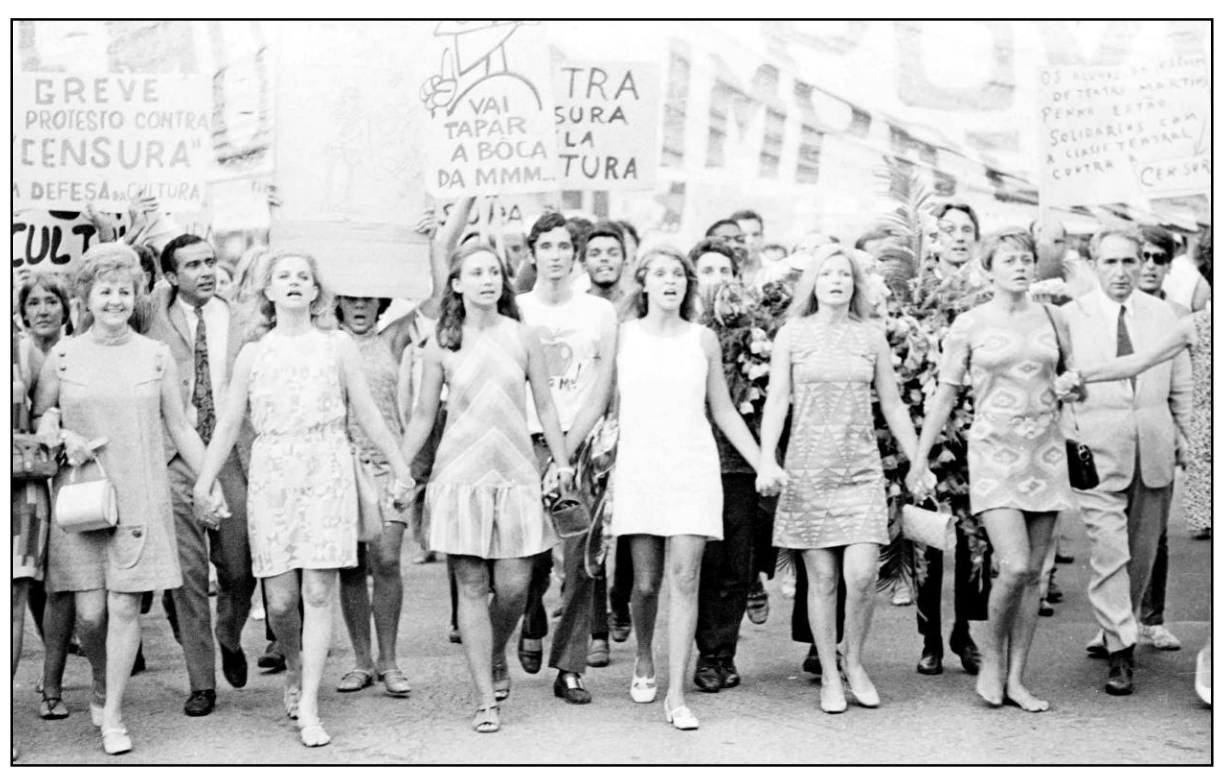

\section{Resumo}

Este estudo elabora sobre o ativismo político das celebridades do showbis. Ele compara os astros americanos e brasileiros, seu impacto social e a maneira através da qual as estrelas militam. As evidências mostram que são raros os casos nos quais elas decidem se comprometer com causas dissidentes. Quando o fazem o impacto é marcante, pois ele chama a atenção da mídia que multiplica seu efeito persuasivo.

Palavras-chaves: Entretenimento. Persuasão. Ativismo. Estrelas 


\section{Abstract}

This study elaborates on the political activism of showbis celebrities. It compares the American and Brazilian stars, their social impact and the manner in which the stars militate. Evidence shows that are rare cases in which they decide to commit to dissidents causes. When they do the impact is striking, since it calls the media attention that multiplies its persuasive effect.

Keywords: Entertainment. Persuasion. Activism. Stars

\section{Resumen}

Este estudio elabora sobre en el activismo político de las celebridades. Compara las estrellas estadounidenses y brasileños, su impacto social y la manera en que las estrellas militan. La evidencia muestra que son casos raros en los que deciden comprometerse a causas disidentes. Quando lo hacen el impacto es sorprendente, ya que llama la atención de los medios que multiplica su efecto persuasivo.

Palabras clave: Entretenimiento. Persuasión. Activismo. Celebridades

Em fevereiro de 1968, artistas e intelectuais se uniram e saíram às ruas do Rio de Janeiro para protestar contra o regime militar brasileiro e seu projeto de censura das artes. ${ }^{1}$ Quarenta e sete anos depois dois remanescentes deste grupo adotaram atitudes políticas distintas. Juca Chaves participou em março de 2015 da manifestação contra a corrupção. ${ }^{2}$ Chico Buarque de Holanda, apoiador do PT, evitou a dissidência. O lugar de destaque na arregimentação da opinião pública para este evento foi ocupado pelo cantor e compositor Lobão. Este personagem soube catalisar o dissabor popular com seu discurso desafiador. Devido às suas posições políticas, ele foi atacado pelo vice-presidente do Partido dos Trabalhadores. Alberto Cantalice rotulou Lobão e mais oito pessoas de "pitbuls da grande mídia". ${ }^{3}$

Essa irritação pressupõe que o endosso de uma celebridade a certa causa política produz efeito relevante na opinião pública. Ela também explica porque esta estratégia tem sido utilizada na publicidade para divulgar produtos e marcas. ${ }^{4}$ Foi o caso, por exemplo, do milionário contrato publicitário firmado em 2014 entre Roberto Carlos e a Friboi. Noutra

\footnotetext{
${ }^{1}$ No grupo estavam Oto Maria Carpeaux, Chico Buarque de Holanda, Alceu de Amoroso Lima, Juca Chaves, Oscar Niemeyer, Abelardo Barbosa (Chacrinha), Carlos Drummond de Andrade, Grande Otelo, Antônio Calado, Djanira, Vinícius de Morais, Tônia Carrero, Di Cavalcanti, Nelson Rodrigues, Gláuber Rocha, Cacilda Becker, Valmor Chagas, Paulo Autran, Bárbara Heliodora e Domingos de Oliveira.

${ }^{2}$ Entre as celebridades que participaram deste protesto estavam também Thamy Miranda, Wanessa Camargo, Malvino Salvador, Christine Fernandes, Daniela Sarahyba, Didi Wagner, Ellen Jabour, Jessika Alves, Marcio Farcia, o ex-jogador Ronaldo, Malvino Salvador, Viviane Pasmantes e Roberta Miranda.

${ }^{3}$ As oito personalidades criticadas em 2012 pelo vice-presidente do PT são Reinaldo Azevedo, Arnaldo Jabor, Demétrio Magnoli, Guilherme Fiúza, Augusto Nunes, Diogo Mainardi, Danilo Gentili e Marcelo Madureira.

${ }^{4}$ Ver https://shopping.yahoo.com/video/celebrity-endorsed-products-worth-035803754.html
} 
PROGRAMA DE PÓS-GRADUAÇÃO EM COMUNICAÇÃO DA UNIVERSIDADE FEDERAL DE SANTA MARIA

campanha similar, Angélica endossou nos comerciais produzidos para a TV os produtos da Perdigão. No campo da política, o endosso político das celebridades sempre interessa à imprensa. ${ }^{5}$

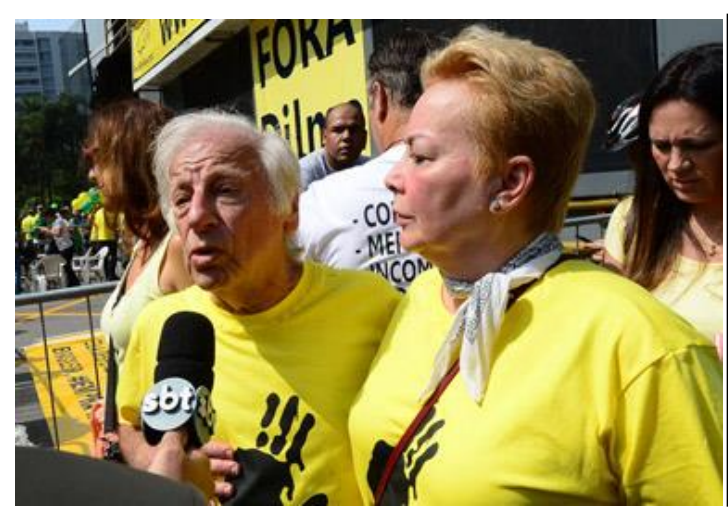

Juca Chaves e sua esposa protestam.

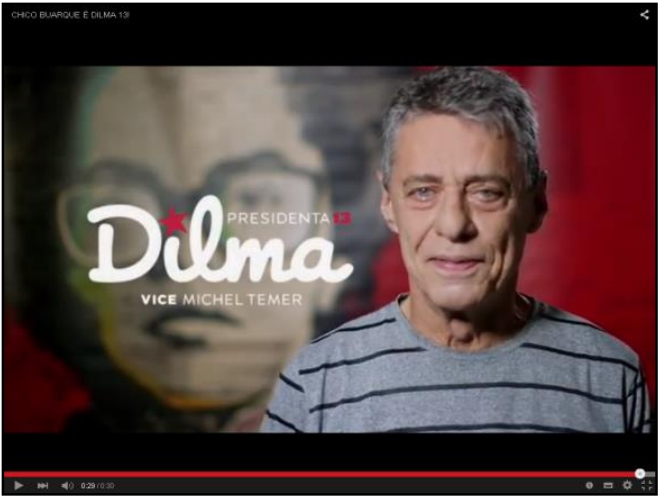

Chico Buarque endossa a candidatura de Dilma.

As manifestações políticas de Juca Chaves, de Chico Buarque de Holanda e de Lobão, e das demais celebridades que se pronunciaram nas eleições de 2014 no Brasil mostram que o ativismo das estrelas acontece em especial nos graves momentos de transição política e de crise social. Este tipo de engajamento tem o efeito de chamar a atenção do público. Os astros oferecem aos atos políticos credibilidade e aura. Foi o caso também de Xuxa, Fernanda Montenegro, Maria Paula, Fernanda Abreu, Cris Vianna e Buchecha que participaram em 2012, no Rio de Janeiro, do evento Veta Dilma em favor da permanência dos royalties do petróleo no Rio de Janeiro. Outro exemplo foi a campanha realizada em 2011, contra a construção da Usina Hidrelétrica de Belo Monte. Participaram astros globais como Ary Fontoura, Bruno Mazzeo, Carol Castro, Ingrid Guimarães, Isis Valverde, Juliana Paes, Cissa Guimarães, Cláudia Ohana, Dira Paes, Letícia Sabatella, Maitê Proença, Malvino Salvador, Elizângela Vergueiro, Eriberto Leão, Guilhermina Guinle, Marcos Palmeira, Murilo Benício, Nathália Dill e Sérgio Marone. Do exterior chegaram gestos de apoio à campanha de James Cameron, Sigourney Weaver e Darryl Hanna.

Chico Buarque diz que em períodos de campanha os artistas são compelidos a se manifestar. ${ }^{6}$ Isso ocorre não só no Brasil como em vários países do mundo (Mukherjee, 2004). Por exemplo, ainda na década de 1920, o cantor e ator Al Jolson apoiou publicamente a candidatura republicana à presidência dos Estados Unidos. Na convenção deste partido em

\footnotetext{
${ }^{5}$ Ver, por exemplo, http://g1.globo.com/politica/eleicoes/2014/noticia/2014/09/artistas-e-celebridades-viram-caboseleitorais-de-luxo-de-presidenciaveis.html

${ }^{6}$ Chico Buarque de Holanda em entrevista à revista Rolling Stones, Edição 61, Outubro de 2011.
} 
PROGRAMA DE PÓS-GRADUAÇÃO EM COMUNICAÇÃO DA UNIVERSIDADE FEDERAL DE SANTA MARIA

2012, Clint Eastwood ironizou o presidente do país ao dramatizar uma conversação imaginária com ele olhando para uma cadeira vazia.

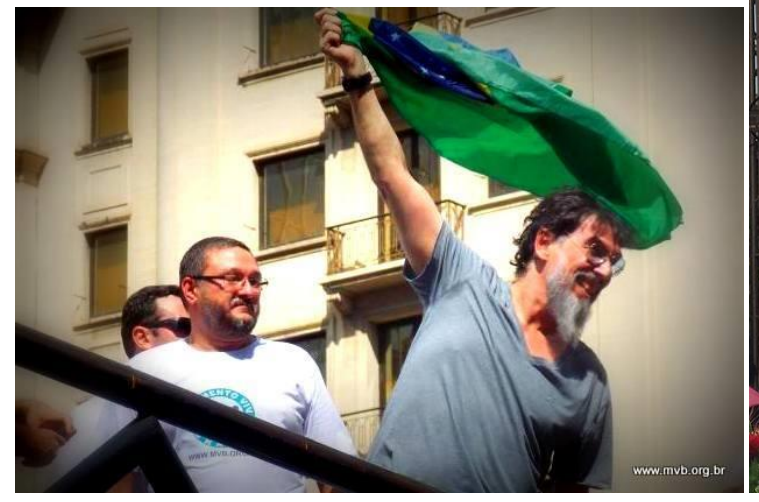

Lobão protesta.

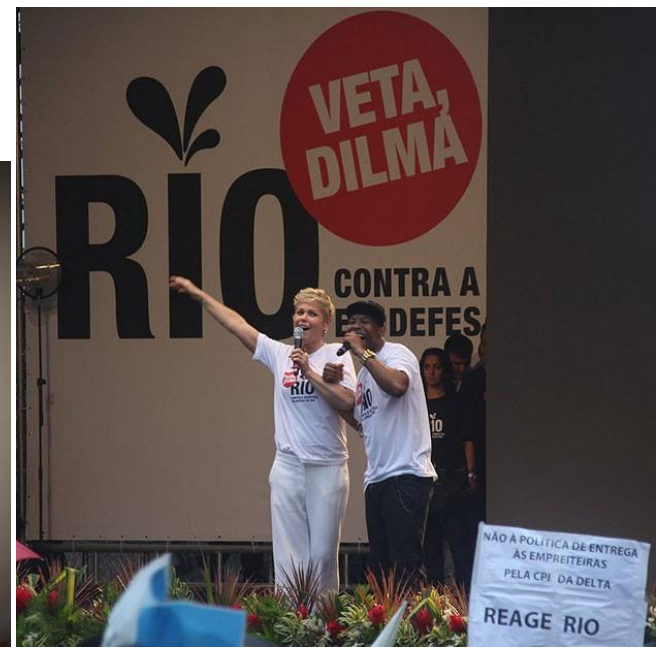

Xuxa vai às ruas.

Astros norte-americanos alinhados ao Partido Democrata também tiveram proeminência na campanha política de 2012, entre eles, Ofrah Winfrey. O clip musical Yes We Can é outro exemplo. Ele uniu na cantoria produzida em favor de Barack Obama as figuras de Scarlett Johansson, Kelly Hu, Tatyana Ali, John Legend, Adam Rodriquez, Herbie Hancock, Kate Walsh, Kareem Abdul Jabbar, Adam Rodriquez, Amber Valetta e Nick Cannon.

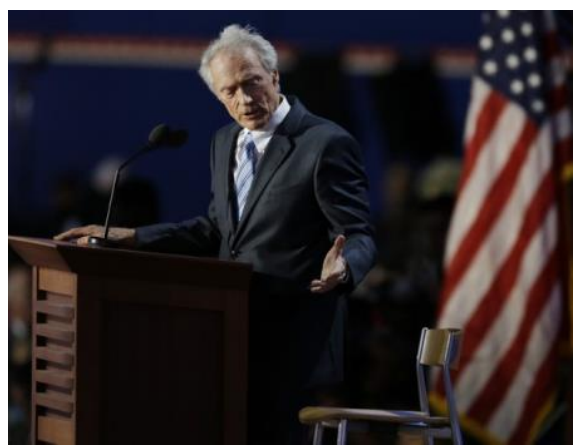

Eastwood ironiza Obama.

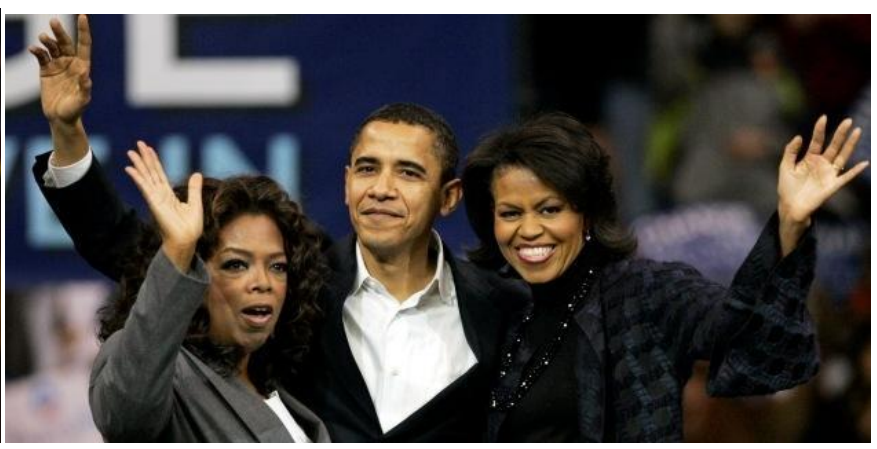

Ofrah apoiou o Presidente dos Estados Unidos.

Em momentos mais amenos, distantes das crises e das eleições, o ativismo estelar é menos polêmico, embora igualmente eficiente. A UNICEF reconheceu o poder de comoção que estas personalidades produzem na divulgação de campanhas humanitárias ao escolhê-las como seus embaixadores. Danny Kaye foi um dos primeiros ainda em 1954. Depois veio Audrey Hepburn. Ela viajou por mais de 20 países dando visibilidade à causa da infância. No 
PROGRAMA DE PÓS-GRADUAÇÃO EM COMUNICAÇÃO DA UNIVERSIDADE FEDERAL DE SANTA MARIA

Brasil os embaixadores escolhidos pela UNICEF são Renato Aragão (1991), Daniela Mercury (1995), o personagem Mônica (2007) e o ator Lázaro Ramos (2009). Na lista dos embaixadores escolhidos noutros países podem ser encontrados bombeiro, corredor de maratonas, orquestra, campeão de sumo, técnico e jogador de futebol, costureiro e modelo, personalidades da televisão, atores e atrizes, músicos e compositores, comediantes, violinista e violoncelista, campeão de surf, artista plástico, escritores, medalhistas olímpicos, jornalistas, políticos, palhaço, ciclista, jogador de basquete, piloto de Fórmula 1, personagem de espetáculo de marionetes, chef de cozinha, malabarista e uma banda de jazz.

O impacto das celebridades na opinião pública é tal que muitas vezes elas se sentem estimuladas a migrar ao mundo da política. Ronald Reagan deixou as telas para atuar como presidente dos Estados Unidos na Casa Branca. O jogador de críquete Imran Khan tornou-se figura popular do cenário político do Paquistão. O esportista Jesse Ventura transformou-se em governador do estado americano de Minnesota entre 1999 e 2003. O ator Arnold Alois Schwarzenegger tornou-se o $38^{\circ}$. governador da Califórnia. O cantor e ator Salvatore Bono tornou-se o prefeito de Palm Springs. No Brasil foram eleitos ao parlamento o costureiro Clodovil, o palhaço Tiririca e os esportistas Romário e Danrlei, entre outros. O músico Gilberto Gil tornou-se ministro do governo de Lula. No Senegal foi o que aconteceu também com o cantor Youssou N'Dour. Este personagem tentou concorrer (e fracassou) à presidência do país em 2012, algo que Silvio Santos tentou fazer em 1989 no Brasil. Na India a estrela de Bollywood, o ator Amitabh Bachchanthe, ocupou por três anos uma cadeira no parlamento do país.

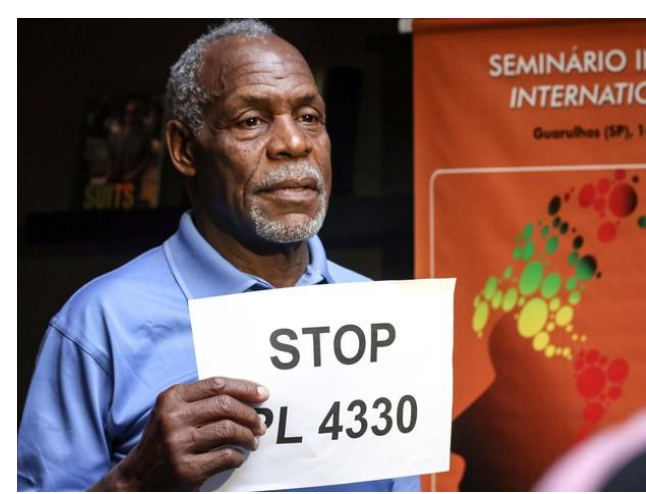

Glover faz política no Brasil.

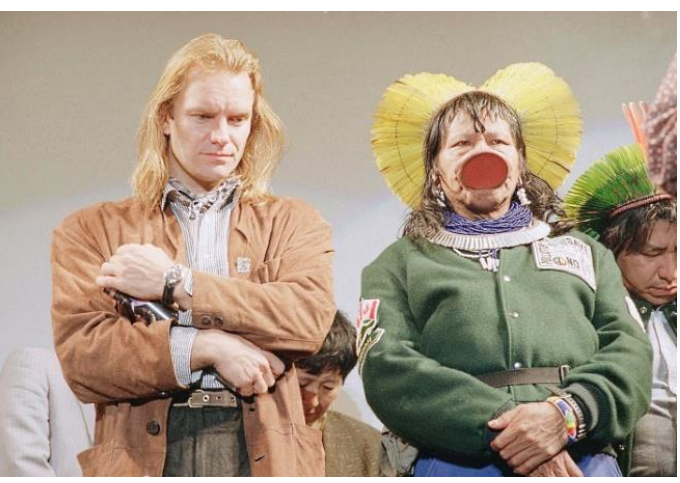

Sting na Amazônia

Como o showbis americano é o mais poderoso do mundo a projeção internacional de suas estrelas é maior do que a dos astros e estrelas de outros países. Por exemplo, a exposição pública de intérpretes da música pop como Madona e Lady Gaga é global. O que elas e outros como elas fazem e dizem tem sempre alguma repercussão. Foi o caso da visita do cantor 
inglês Sting à Amazônia em 1987. Ele deu visibilidade à devastação da floresta (irritando sobremaneira as autoridades brasileiras da época). Em certos momentos, militantes políticos nacionais se valem de celebridades internacionais para divulgar suas causas paroquiais. Este foi o caso do ator americano Danny Glover. Em sua visita ao Brasil em maio de 2015, ele protestou contra a proposta de lei referente à regulamentação do trabalho terceirizado que estava em discussão no Congresso nacional.

As estrelas desfrutam no campo da política da aura mítica que elas produzem e cultivam no campo do entretenimento. Em decorrência, as câmeras de televisão, os paparazzi e a mídia popular seguem seus passos nas andanças que fazem de um lado ao outro destes dois universos. A tabela abaixo mostra a projeção internacional dos atores, cantores, músicos e escritores norte-americanos. Este grupo supera a repercussão publicitária produzida pelos políticos daquele país em todo o mundo. Entre os astros destacam-se, por ordem decrescente de poder de influência, Marilyn Monroe, Bruce Lee, Charlie Chaplin, Marlon Branco, Al Pacino, Marlene Dietrich, Andrey Hepburn, Clint Eastwood, Robert De Niro e Jack Nicholson. ${ }^{7}$ A classe artística e intelectual francesa, em especial os escritores, é a mais influente do país internacionalmente. É o que ocorre também na Grã-Bretanha.

Os políticos brasileiros, em especial os mais antigos, tem mais destaque internacional do que os personagens do showbis e da cultura nacional. Entre eles estão Getúlio Vargas e Dom Pedro II. Em segundo lugar está a classe dos esportistas, em especial os jogadores de futebol.

\begin{tabular}{|l|l|l|l|l|}
\hline & $\begin{array}{l}\text { Brasil } \\
\mathbf{\%}\end{array}$ & $\begin{array}{l}\text { França } \\
\mathbf{\%}\end{array}$ & $\begin{array}{l}\text { Estados Unidos } \\
\mathbf{\%}\end{array}$ & $\begin{array}{l}\text { Grã-Bretanha } \\
\mathbf{\%}\end{array}$ \\
\hline $\begin{array}{l}\text { Período } \\
\text { considerado }\end{array}$ & $\mathbf{1 8 0 0 - 1 9 5 0}$ & $\begin{array}{l}\mathbf{4 0 0 0} \text { a.C- 2010 } \\
\text { d.C }\end{array}$ & $\begin{array}{l}\mathbf{4 0 0 0} \text { a.C. - 2010 } \\
\text { d.C }\end{array}$ & $\begin{array}{l}\mathbf{4 0 0 0} \text { a.C. - 2010 } \\
\text { d.C }\end{array}$ \\
\hline Atores & - & 5,16 & 32,90 & 16,61 \\
\hline Cantores & - & - & 7,91 & 4,72 \\
\hline Músicos & 7,69 & - & 7,21 & 8,26 \\
\hline Escritores & 5,77 & 14,20 & 6,74 & 9,98 \\
\hline Políticos & 42,31 & 16,90 & 6,22 & 13,70 \\
\hline $\begin{array}{l}\text { Jogadores de } \\
\text { Futebol }\end{array}$ & 17,31 & 7,39 & - & 8,35 \\
\hline Pintores & - & 5,05 & - & - \\
\hline Compositores & - & 4,11 & - & - \\
\hline
\end{tabular}

Quadro 1: Quem são as pessoas mais conhecidas no mundo nascidas nestes países?

Fonte: Pantheon - MIT

A UNICEF classifica as estrelas globais de embaixadores internacionais. O brasileiro Sebastião Salgado é um deles. Os já mencionados Amitabh Bachchanthe, David Beckham, 
PROGRAMA DE PÓS-GRADUAÇÃO EM COMUNICAÇÃO DA UNIVERSIDADE FEDERAL DE SANTA MARIA

Mia Farrow e Youssou N'Dour também são. Nesta lista estão ainda nomes como Jessica Lange (atriz), Ricky Martin (cantor), Roger Federer (tenista) e Woopy Goldberg e Vanessa Redgrave (atrizes).

O que todas estas celebridades têm em comum é o fato de serem capazes de influenciar a agenda política e social com seu ativismo. Brigitte Bardot abandonou o cinema em 1974 para se dedicar à causa dos direitos dos animais. Angelina Jolie tem andado pelo mundo como embaixadora do Alto Comissariado das Nações Unidas para os Refugiados. O cantor Bono tornou-se figura da diplomacia internacional ao se concentrar no ativismo em favor da causa do combate à pobreza na África e à AIDS (Tsaliki, 2011). Madona aproveita seus espetáculos para provocar o público com temas polêmicos e para difundir a causa da tolerância religiosa. Lady Gaga defende em seus manifestos políticos o direito dos gays de servirem nas forças armadas do país.

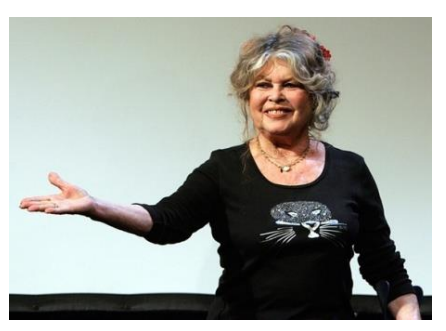

Bardot protege animais.

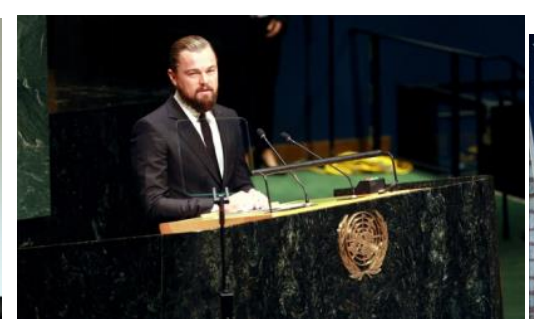

DiCaprio fala na ONU.

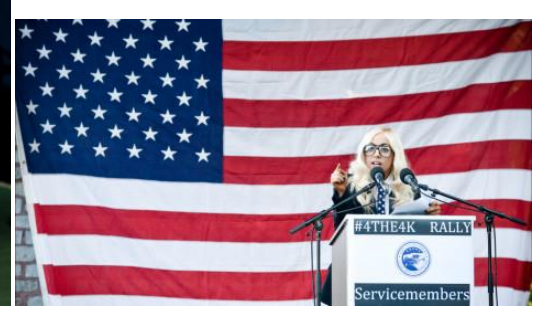

Lady Gaga discursa em favor dos gays.

No caso dos Estados Unidos, geralmente há alguma Fundação que catalisa a atenção do público e gerencia as doações financeiras que surgem em decorrência das campanhas promovidas por estas figuras. ${ }^{8}$ Este é o caso, por exemplo, da Fundação Ian Somerhalder (www.isfoundation.com). Este ator promove a causa ambiental e a defesa dos animais. Ele anima os 750 mil fãs que seguem sua conta no twitter com suas mensagens. Outro exemplo ainda é a Fundação Keep a Child Alive da cantora Alicia Keys. O objetivo desta organização é fazer chegar medicamentos a famílias portadoras do vírus HIV na África. Já Bianca Jagger atua como Embaixadora da Boa Vontade do Conselho da Europa e sua fundação se dedica ao tema dos direitos humanos.

A popularidade facilita contatos destas estrelas com as autoridades assim como lhes assegura presença constante na mídia. Os microfones, as câmeras e os pódios lhes são oferecidos com relativa facilidade. George Clooney, por exemplo, se pronunciou no Conselho de Segurança da ONU ao lado do Nobel da Paz, Elie Wiesel, em favor da intervenção militar

\footnotetext{
${ }^{8}$ Ver http://www.celebopedia.net/ 
PROGRAMA DE PÓS-GRADUAÇÃO EM COMUNICAÇÃO DA UNIVERSIDADE FEDERAL DE SANTA MARIA

na região de Darfur no Sudão. Angelina Jones falou a estes embaixadores sobre a situação na Síria após sua visita ao país.

\section{ATIVISMO}

Graças às redes sociais observam-se hoje dois tipos de ativismos. $\mathrm{O}$ primeiro é o da celebridade. No passado, o astro costumava escrever cartas manuscritas e enviar o texto assinado ao fã junto a sua foto. Era assim que ele administrava sua imagem pública. Usualmente, este personagem também contratava um administrador de carreira que enquadrava sua figura no imaginário coletivo. Depois, o desenvolvimento da mídia popular e das redes sociais modernas, em especial o twitter, tornou esta tarefa mais complexa (Muntean, 2009).

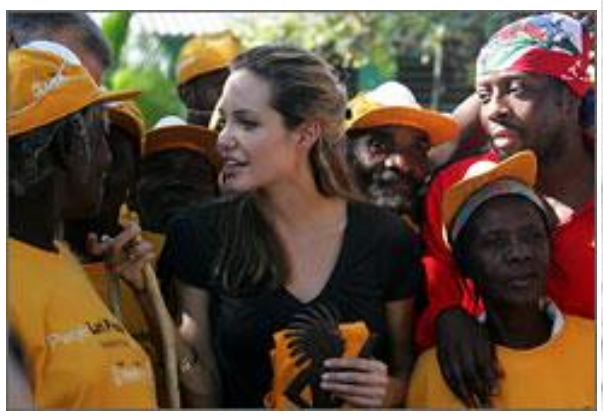

Jolie e os refugiados.

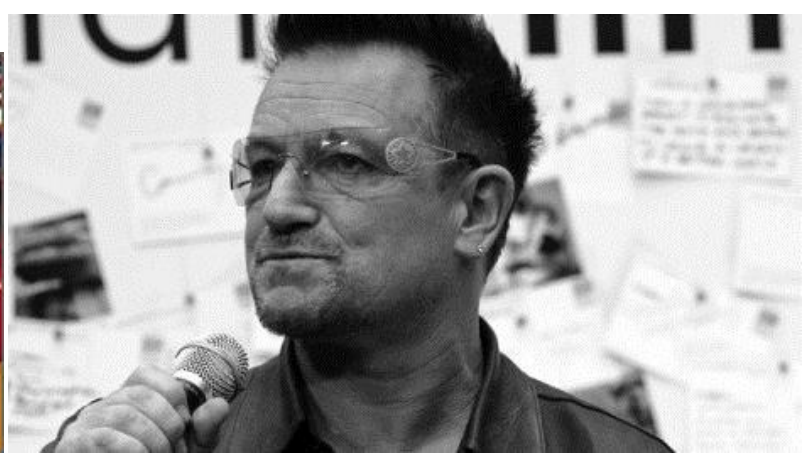

Bono e a África.

Em março de 2015, cerca de 67 milhões de pessoas seguiam a cantora pop Katty Perry em todo o mundo. Em segundo lugar estava o cantor Justin Bieber (61 milhões). Vinham depois as cantoras Taylor Swift (54 milhões) e Lady Gaga (45 milhões), o cantor Justin Timberlake (43 milhões) e as cantoras Rihanna (42 milhões) e Britney Spears (41 milhões). Nesta lista dos 10 mais populares no Twitter o único político presente era Barack Obama (56 milhões de seguidores). O Papa Francisco era a segunda autoridade internacional mais seguida (14 milhões). Dilma Rousseff estava na $14^{\mathrm{a}}$. posição com 2,45 milhão de seguidores. Ou seja, hoje em dia a relação de um astro com o seu público é direta. Graças ao Facebook, Twitter e o You Tube o personagem também pode mobilizar os fãs de sua rede social às suas causas humanitárias e políticas.

Tais redes virtuais autorizam ainda um segundo tipo de ativismo, a dos fãs (Earl, 2009). A história do rádio brasileiro mostra que esta prática é antiga. Exemplo é a acirrada disputa que os simpatizantes de Emilinha Borba e Marlene travavam entre si. ${ }^{9}$ Ambas as 
PROGRAMA DE PÓS-GRADUAÇÃO EM COMUNICAÇÃO DA UNIVERSIDADE FEDERAL DE SANTA MARIA

cantoras competiam pelo título de Rainha do Rádio e suas apresentações eram acompanhadas por audiências apaixonadas. Como se observa, o star system criado pela indústria cinematográfica de Hollywood difundiu-se à mídia em geral. O que está em jogo, portanto, é a personalidade do astro. E é ela que anima a imprensa popular e o gosto dos fãs pela vida privada do personagem.

Esta popularidade é avaliada no Brasil através de uma métrica conhecida como DavieBrown Index (DBI). Este indicador monitora cerca de 300 celebridades brasileiras e 300 globais. Neymar é a personalidade mais conhecida do público nacional (nota 98.24) seguido por Ivete Sangalo $(98,22)$ e Gisele Bündchen (98). O DBI mede o grau de reconhecimento da celebridade pelo público, o nível de aceitação de suas recomendações, o seu potencial como formador de opinião, o nível de reconhecimento de sua carreira pela audiência e o seu grau de influência e confiança. ${ }^{10}$ Outra métrica bastante popular é o Q Score. Este indicador mede a popularidade de 25 mil celebridades em todo o mundo, o nível de afeto do público por eles e o grau de apelo popular destas figuras. ${ }^{11}$

\begin{tabular}{|l|l|l|l|l|}
\hline 1. Sean Connery & $\begin{array}{l}\text { 2. Anthony } \\
\text { Hopkins }\end{array}$ & 3. Liam Neeson & $\begin{array}{l}\text { 4. David } \\
\text { McCallum }\end{array}$ & $\begin{array}{l}\text { 5. Daniel Day- } \\
\text { Lewis }\end{array}$ \\
\hline 6. Judi Dench & 7. Maggie Smith & 8. Daniel Craig & 9. Hugh Laurie & $\begin{array}{l}\text { 10. James } \\
\text { Purefoy }\end{array}$ \\
\hline
\end{tabular}

Quadro 2: Os astros de Hollywood com maiores Q Scores em 2013

Sair do anonimato e alcançar as luzes da ribalta torna-se obsessão para algumas pessoas. Isso ocorre quando os fãs encontram alguma razão para cultuar a imagem do personagem, a que a mídia oferece ao desfrute da audiência. Trata-se, portanto de um status que resulta de uma opinião acalentada pelos receptores. Ao vencer as restrições impostas pela audiência à sua ascensão ao panteão mágico da adoração coletiva, o personagem transpõe a fronteira existente entre o território pagão e o mundo 'mágico' da fantasia. A partir de então o astro passa a cultivar certo mistério, preocupa-se em manter uma distância do público e a permitir certo nível de circulação de rumores sobre si, entre outras atitudes manipuladoras que visam mitificar sua figura (Milner, 2005).

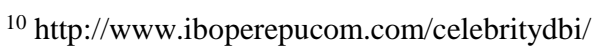

${ }^{11} \mathrm{O}$ Q Score das celebridades da TV americana pode ser obtido em http://www.thewrap.com/fall-tv-q-scores-jim-parsonspatrick-dempsey-chris-pratt-dylan-mcdermott-eric-stonestreet/
} 
O que autoriza o lançamento de uma pessoa ao estrelato é sempre algum fato ou ato excepcional. $\mathrm{O}$ interesse da mídia pelo personagem é uma consequência e vem sempre a reboque deste tipo de desempenho dramatúrgico através da qual ele enlaça a atenção do público (Tufekci, 2013). Segundo a clássica definição, uma celebridade é uma pessoa que se tornou famosa por ser famosa (Boorstin, 1992). Exemplos clássicos bastante referidos deste tipo de ocorrência são as figuras de Paris Hilton e as irmãs Kardashian. No Brasil casos similares são Adriane Galisteu, Nicole Bahls e Geisy Arruda. Muitas celebridades são egressas de programas de auditórios, de concursos de beleza e de reality shows, entre outras atrações da mídia. Resulta que tais figuras desfrutam por algum tempo de alguma popularidade e com ela a tiracolo tentam construir uma carreira. No exterior foram criados neologismos para este tipo de fenômeno, entre eles Famesque e Celebutantes. Como salientado, o problema é o primeiro passo que o personagem dá para vencer a resistência e o desinteresse do auditório (Driessens, 2012). Isso permite afirmar que necessariamente a persona de uma celebridade é sempre um bem simbólico manufaturado (Meyer, 1995).

Este é um desafio presente também nos estágios seguintes. O personagem sabe que terá o status de celebridade enquanto puder cultivar o apreço das massas. Por isso mesmo, em suas manifestações públicas, boa parte das estrelas respeita os limites impostos pelo senso comum. Elas geralmente evitam temas polêmicos como são os casos da política, da economia e das disputas sindicais e laborais (Meyer, 1995). No Brasil, Pelé é exemplo mais bem acabado deste tipo de comportamento. Ao se dedicar a administrar sua reputação de Rei, Pelé se tornou mestre da arte das relações públicas e do branding pessoal. Roberto Carlos é outro Rei que se mostrou hábil na administração de sua exposição pública, a despeito das críticas que sofre por ser apolítico e manipulador. ${ }^{12}$

Por decorrência, os temas mais populares deste tipo de ativismo estelar são os sociais e os inclusivos: a assistência social, a saúde, o bem estar das crianças, a preservação do ambiente, a assistência humanitária internacional, a educação e o direito dos animais (Thael et all., 2008).

Os casos referidos permitem fazer uso de dois conceitos apresentados por Driessens (2012). Com eles é possível apresentar dois modelos de comunicação. O primeiro se refere à 'celebritização' da política. Ou seja, as estrelas servem ao mesmo tempo de fonte e de canal à difusão de mensagens persuasivas. O receptor é o fã. Num lado está a aura da estrela e no

\footnotetext{
${ }^{12}$ Urariano Mota. 'O Rei Roberto Carlos e a ditadura militar no Brasil.' Carta Capital. 05/05/2005 Ver também http://entretenimento.r7.com/blogs/ricardo-alexandre/roberto-carlos-esta-so-comecando-a-pagar-por-seudesprezo-pelo-jornalismo-e-pela-historia-20150105/
} 
PROGRAMA DE PÓS-GRADUAÇÃO EM COMUNICAÇÃO DA UNIVERSIDADE FEDERAL DE SANTA MARIA

outro a admiração, a emoção e a fé do público. Desta forma a mídia massiva (broadcasting), a que enquadra e dissemina a figura mítica do astro no imaginário coletivo, é a que autoriza seu ativismo na mídia social (narrowcasting). Este é o caso em que predomina a comunicação consensual.

Comunicação consensual - celebritização da política -
\begin{tabular}{|lll|}
\hline BROADCASTING & Mídia Massiva & Aura \\
NARROWCASTING & Twitter/Internet & Admiração da mídia massiva) \\
\hline
\end{tabular}

Microcelebridade (astro do ativismo na web)

O segundo modelo é o inverso do primeiro e foi denominado por Driessens (2012) de ‘celebrificação'. É o caso no qual o narrowcasting condiciona o broadcasting. Este modelo ajuda a explicar a ocorrência na qual a 'microcelebridade' (Tufekci, 2013) sai do anonimato e migra às emissoras de televisão e ao showbis graças à sua atuação bem sucedida na web. Foi o caso, por exemplo, de Rafinha Bastos. No início da carreira ele ficou conhecido pelas paródias de videoclipes famosos que divulgava na web. Depois se tornou figura popular da mídia. Agora se estima que ele possua 2,8 milhões de seguidores no twitter.

Algo similar acontece no campo da política. Anônimos militantes tornam-se celebridades da mídia massiva, ou macrocelebridades, graças ao sucesso do ativismo virtual, algo que às vezes é chamado de slacktivismo. Este neologismo (pejorativo) foi criado pela combinação de dois termos em inglês, slacker e activism, ou seja, o ativismo do preguiçoso, de alguém que se limita a mobilizar o público através da internet, evitando outra forma de engajamento político mais exigente. Por isso o termo foi adaptado ao Brasil como sendo ‘sofativismo' e 'clictivismo'.

Comunicação dissidente - celebrificação da política (astro do ativismo na web) NARROWCASTING Twitter/Internet BROADCASTING Mídia Massiva Microcelebridade

Macrocelebridade (astro da mídia massiva)

\section{ESTUDO}

A comunicação dissidente se propõe a desafiar os padrões morais, políticos e culturais estabelecidos pelo senso comum. Ela expressa o desconforto e a oposição que um ator cultiva a um ou a vários aspectos de certo sistema social. Ou seja, o dissidente confronta as crenças 
PROGRAMA DE PÓS-GRADUAÇÃO EM COMUNICAÇÃO DA UNIVERSIDADE FEDERAL DE SANTA MARIA

estabelecidas e manifesta sua crítica publicamente. Esta comunicação dissidente se difunde na sociedade através de meios convencionais e alternativos, entre eles, por exemplo, o cinema, a música, as artes, o jornalismo, o teatro e a web, entre outros. Este tipo de ativismo crítico não se equipara às atitudes humanistas que caracterizam o comportamento altruísta. A comunicação dissidente divulga uma atitude política de contestação. Sua mensagem é desviante. Ela oferece alternativa e enfrenta, em alguma medida, às narrativas existentes (Wainberg, 2016A).

A excepcionalidade deste tipo de atitude entre as estrelas foi analisada por Kapoor (2012) e Brockington (2011). Segundo esta interpretação crítica, as doações milionárias de Bill Gates, a maratona televisiva que Jerry Lewis costumava realizar no Dia do Trabalho para arrecadar milhões de dólares ao combate da distrofia muscular e a adoção multicultural de filhos por Angelina Jolie e por seu marido Brad Pitt são exemplos de um espetáculo humanístico que serve mais aos fins das relações públicas destes personagens do que aos objetivos de uma crítica social reformadora. Ou seja, e generalizando, a ação filantrópica dos personagens do showbis, embora custe dinheiro e energia, resulta em publicidade e fama, nutrientes que as celebridades dependem para viver (e sobreviver).

Cabe analisar, portanto os casos excepcionais nos quais algumas celebridades optam em dar visibilidade a causas polêmicas e também impopulares (Wainberg, 2010). Por exemplo, em 1973, Marlon Brando recusou o Oscar por sua atuação em O Grande Chefão. Ele mandou em seu lugar uma índia apache para discursar no palco da cerimônia da entrega do prêmio. Esta foi a sua maneira de protestar contra o tratamento dado aos nativos americanos pela indústria cinematográfica dos Estados Unidos. Algo similar fez a cantora pop Miley Cyrus em 2014. Ela enviou um homeless para receber o prêmio de melhor clip musical. Com este gesto ela manifestou seu mal-estar com o desamparo que atinge milhares de pessoas neste país. Na França, em 2013, Alain Delon tornou-se cabo eleitoral do candidato de extrema-direita Le Pen e de seu partido Frente Nacional. O gesto surpreendeu a opinião pública do país e ganhou enorme destaque internacional. Com sua atitude ele manifestou sua crítica à política imigratória da França. 
PROGRAMA DE PÓS-GRADUAÇÃO EM COMUNICAÇÃO DA UNIVERSIDADE FEDERAL DE SANTA MARIA

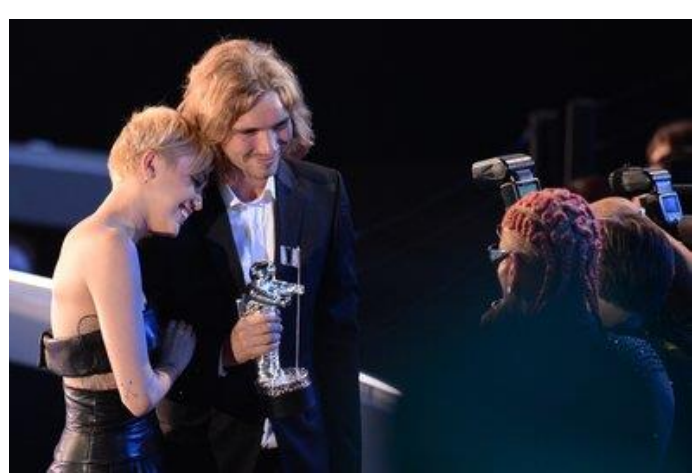

Homeless recebe prêmio.

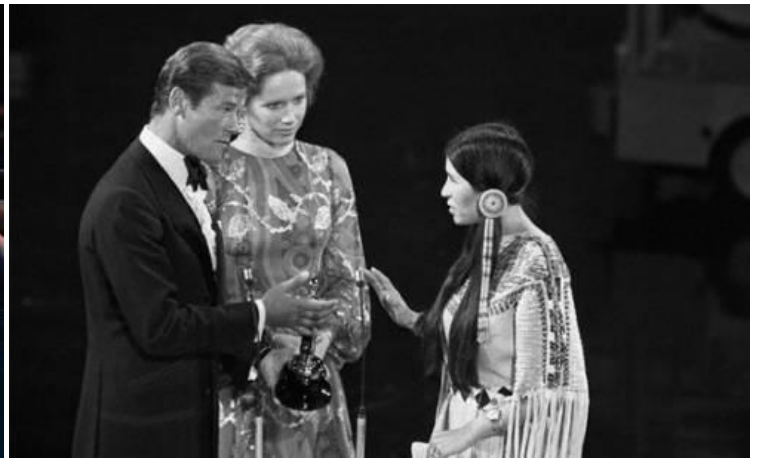

Índia apache recebe o Oscar.

Outro exemplo é o cantor de música country Johnny Cash. Ele arriscou a carreira ao defender os índios americanos numa época em que isso era incomum. Em 1964, Cash gravou o disco Bitter Tears: Ballads of the American Indian. O tema do álbum era a história e o sofrimento dos indígenas de seu país. O ator Harry Belafonte e o cineasta Oliver Stone apoiaram Hugo Chaves. Seu documentário South of the Border apresentado no Festival de Veneza em 2009, é uma celebração do falecido presidente da Venezuela. Em 1968, a atriz Jane Fonda decidiu visitar o Vietnã do Norte em protesto contra a intervenção americana na Indochina repetindo o gesto da escritora Susan Sontag que tomara essa mesma atitude.

Cabe lembrar também o ator Sean Penn. Ele apoiou a Argentina contra a Inglaterra na guerra travada entre os dois países pelo controle das ilhas Malvinas/Falklands. Sean Penn também o visitou o Iraque antes da invasão deste país pelas tropas americanas. Ele pagou 56 mil dólares para publicar em 2002, um anúncio no jornal Washington Post contra a política e a ação militar do governo dos Estados Unidos. Charlie Sheen também têm vocalizado duras críticas à administração americana. É o caso ainda da música “American Idiot” cantada pela banda Green Day. A atriz francesa Marion Cotillard, conhecida no mundo por sua interpretação no filme Piaf, manifestou suas dúvidas sobre a autenticidade da versão americana do ataque terrorista aos Estados Unidos em 2011. John Lennon ainda é venerado pelos críticos dos Estados Unidos por sua ação dissidente no período da guerra do Vietnã (Easterly, 2010). Cabe lembrar que além de formar uma das mais célebres bandas de rock ele se envolveu com dissidentes, entre eles Jerry Rubin, Abbie Hoffman, John Sinclair e o movimento Panteras Negras.

No mundo árabe destaca-se o papel desempenhado pela cantora Assala. Desde o início da rebelião civil na Síria em 2011 ela divulga através das emissoras árabes de TV por satélite e da internet sua mensagem de protesto contra o regime de Bashar al-Assad. Este tipo de transgressão política é comportamento raro neste ambiente no qual a classe artística 
usualmente é cooptada pela autoridade. Na Tunísia a cantora pop Latifa tem sido criticada por ter se pronunciado contra o regime de seu país somente após a derrubada do ditador Zine elAbidine Ben Ali. ${ }^{13}$ A moderação e a discrição foi o comportamento escolhido pelos artistas egípcios durante os protestos realizados por populares na praça Tahrir contra o regime de Hosni Mubarak em 2011. Na oportunidade o cantor pop Amr Diab chegou a abandonar o país num avião particular. ${ }^{14}$ Esta atitude se explica devido à preferência dos astros egípcios por governantes fortes capazes e dispostos a enfrentar os islamitas, seus principais críticos e opositores. É o que parece explicar também a preferência da atriz síria Raghda por Bashar alAssad (Kraidy, 2015). ${ }^{15}$

Quando a dissidência passa a ser ocorrência consensual e o protesto se dissemina na opinião pública o número de celebridades que se engaja no protesto tende a crescer. E quanto maior é o número de estrelas que participa da contestação maior é a força do movimento em atrair os demais astros relutantes e temerosos da reação de seus fãs. O movimento pelas Diretas Já é exemplo disso. O ato alcançou seu apogeu em 16 de abril de 1984. Nesta oportunidade, 1,5 milhão de pessoas se reuniu no comício realizado na Praça da Sé em São Paulo. Participou da manifestação o maior número de celebridades já reunido num ato de protesto da história do Brasil. Estiveram presentes atrizes, atores, cantores, poetas, humoristas e intelectuais, entre outros. Foram os casos de Priscilla Camargo, Juca Kfouri, Mario Lago, Raul Cortez, Jô Soares, Rita Lee, Dina Sfat, Henfil, Irene Ravache, Kito Junqueira, Tânia Alves, Bete Mendes, Fafá de Belém, Chico Buarque de Holanda, Elba Ramalho, Alceu Valença, Jards Macalé, Gilberto Gil, Cristiane Torloni, Fernanda Montenegro e os jogadores de futebol Sócrates, Casagrande e Vladimir.

Este mesmo fenômeno aconteceu em 2015. O movimento Vem Pra Rua obteve o endosso dos atores Luigi Barcelli, Caio Castro, Jovane Nunes, Marcelo Serrado, Kadu Moliterno, Márcio Garcia, do cantor Latino e das atrizes Alessandra Maestri, Thayla Ayala, Christine Fernandes, entre outros. Eles gravaram vídeos com seus comunicados dissidentes e os divulgaram no You Tube. Entre todos, Lobão se destacou por não se intimidar com as críticas recebidas em 2012 e também por denunciar o PT em seu hino A Marcha dos Infames. ${ }^{16}$ Em julho de 2015 ele voltaria a carga ao lançar seu álbum político "Rigor e Misericórdia". Falcão do grupo $O$ Rappa convocou a população às manifestações com a música Vem Para

\footnotetext{
${ }^{13}$ https://www.youtube.com/user/LaTiFa

${ }^{14} \mathrm{https}: / / \mathrm{www}$.youtube.com/watch?v=dK2U-0U0hA4

${ }^{15} \mathrm{https}: / / \mathrm{www}$. youtube.com/watch?v=R3QwSEU_Aqg

${ }^{16} \mathrm{https} / / / \mathrm{www}$.youtube.com.watch?v=YPeMgaDF6AQ
} 
Rua. ${ }^{17}$ Juca Chaves, por sua vez, ironizou os corruptos e o partido do governo em sua modinha satírica Adeus em Ritmo de Lava-Jato. ${ }^{18}$

\section{ESTUDO}

Considerando os critérios utilizados pela revista Forbes para definir a sua lista das 100 celebridades mais poderosas do mundo - a renda, os cliques no Google, o tamanho do fã clube, o número de matérias publicadas na imprensa sobre o personagem e o número de capas de revista que estampam sua figura - tem-se nesta nominata um total de 89 personagens, entre eles 28 atores/atrizes, 10 personalidades do rádio e da televisão, 13 esportistas, dois escritores, três cineastas, 32 músicos e cantores e um empresário. Ao todo 65 são americanos, 10 são ingleses, seis são canadenses, dois são irlandeses e dois são originários da ilha de Barbados, um é australiano, outro é suíço. Há ainda um alemão e um neozelandês. Levando em conta as frequências nestas listas no período entre 1999 e 2014 tem-se este ranking de personalidades:

\begin{tabular}{|c|c|c|c|c|}
\hline Ranking & Nome & $\begin{array}{l}\text { Frequência } \\
\text { entre } 1999 \text { e } \\
2014\end{array}$ & Atividade & Nacionalidade \\
\hline 1 & Oprah & 16 & $\begin{array}{l}\text { Apresentadora } \\
\text { de TV }\end{array}$ & USA \\
\hline \multirow[t]{2}{*}{2} & $\begin{array}{l}\text { Steven } \\
\text { Spielberg }\end{array}$ & 14 & Cineasta & USA \\
\hline & $\begin{array}{l}\text { Tiger } \\
\text { Woods } \\
\end{array}$ & 14 & $\begin{array}{l}\text { Jogador de } \\
\text { Golfe }\end{array}$ & USA \\
\hline \multirow[t]{5}{*}{3} & $\begin{array}{l}\text { Angelina } \\
\text { Jones }\end{array}$ & 6 & Atriz & USA \\
\hline & $\begin{array}{l}\text { Johnny } \\
\text { Depp }\end{array}$ & 6 & Ator & USA \\
\hline & Madona & 6 & Cantora & USA \\
\hline & $\begin{array}{l}\text { The Rolling } \\
\text { Stones }\end{array}$ & 6 & $\begin{array}{l}\text { Banda de } \\
\text { músicos }\end{array}$ & USA \\
\hline & Tom Cruise & 6 & Ator & USA \\
\hline \multirow[t]{5}{*}{4} & Beyoncé & 5 & Cantora & USA \\
\hline & $\begin{array}{l}\text { Britney } \\
\text { Spears }\end{array}$ & 5 & Cantora & USA \\
\hline & $\begin{array}{l}\text { George } \\
\text { Lucas }\end{array}$ & 5 & Cineasta & USA \\
\hline & $\begin{array}{l}\text { Michael } \\
\text { Jordan }\end{array}$ & 5 & $\begin{array}{l}\text { Jogador de } \\
\text { basquete }\end{array}$ & USA \\
\hline & Tom Hanks & 5 & Ator & USA \\
\hline \multirow[t]{7}{*}{5} & Brad Pitt & 4 & Ator & USA \\
\hline & $\begin{array}{l}\text { David } \\
\text { Letterman }\end{array}$ & 4 & $\begin{array}{l}\text { Apresentador de } \\
\text { TV }\end{array}$ & USA \\
\hline & Jay Z & 4 & Músico & USA \\
\hline & $\begin{array}{l}\text { Kobe } \\
\text { Bryant }\end{array}$ & 4 & $\begin{array}{l}\text { Jogador de } \\
\text { basquete }\end{array}$ & USA \\
\hline & Lady Gaga & 4 & Cantora & USA \\
\hline & $\mathrm{U} 2$ & 4 & Banda Pop & Irlanda \\
\hline & Will Smith & 4 & Ator & USA \\
\hline
\end{tabular}

\footnotetext{
${ }^{17}$ https://www.youtube.com/watch?v=DIMAZRrsJ_w

${ }^{18} \mathrm{https}: / /$ www.youtube.com.com/watch?v=vHKojTFyzNk 
PROGRAMA DE PÓS-GRADUAÇÃO EM COMUNICAÇÃO DA UNIVERSIDADE FEDERAL DE SANTA MARIA

No Brasil este ranking foi produzido pela primeira vez em 2013. Neymar era em 2014, o líder com 120 mil menções na mídia nacional. Ele contava com 48,5 milhões de 'amigos' no Facebook, além de 15 milhões de seguidores no twitter e 12 milhões de seguidores no Instagram. Na elaboração da listagem nacional a Revista Forbes considerou os critérios de renda, o grau de notoriedade do personagem, sua popularidade, sua longevidade na carreira, sua exposição no noticiário e seu desempenho nas redes sociais. Segundo a publicação, estas celebridades são as que têm mais capacidade de mobilizar seguidores.

Cabe perguntar se o fazem e para quê? Cabe também comparar o desempenho dos brasileiros com o obtido na listagem das celebridades estrangeiras. Para tanto, este estudo aplica a metodologia proposta por Thrall (2008). Faz-se uma análise dos websites dos astros para verificar seu perfil e referência a eventual ativismo. O mesmo procedimento é feito em outras fontes - fã clubes, Wikipédia, etc. Por fim, uma pesquisa na web é feita com base no nome do personagem e os verbetes ativismo e política e assim verificar em que medida os astros do showbis e da mídia servem de canal à comunicação dissidente.

\begin{tabular}{|c|c|c|c|c|}
\hline $\begin{array}{l}\text { Celebridades } \\
\text { Brasileiras }+ \\
\text { poderosas }\end{array}$ & Ativismo & $\begin{array}{l}\text { Obra Social } \\
\text { Financiamento e/ou } \\
\text { participação em obra } \\
\text { filantrópica }\end{array}$ & $\begin{array}{l}\text { Atuação política } \\
\text { Participação em movimento } \\
\text { político/declaração e } \\
\text { engajamento político }\end{array}$ & Site oficial \\
\hline Pelé & Social & $\begin{array}{l}\text { Complexo Pequeno } \\
\text { Príncipe. }\end{array}$ & Inerte & http://www.pele10.com/ \\
\hline Ronaldo & Político & Inerte & $\begin{array}{l}\text { Participação no ato de } \\
\text { protesto contra a } \\
\text { corrupção. }\end{array}$ & http://www.ronaldohome.com/ \\
\hline Neymar & Social & $\begin{array}{l}\text { www.institutoneymarjr } \\
\text {.org.br/ }\end{array}$ & Inerte & http://www.neymaroficial.com/nav/ \\
\hline Ivete Sangalo & Inerte & Inerte & Inerte & http://www.parabensveveta.com.br/ \\
\hline $\begin{array}{l}\text { Gisele } \\
\text { Bundchen }\end{array}$ & Social & $\begin{array}{l}\text { http://giselebundchen- } \\
\text { online.com/fanfacts/ }\end{array}$ & Inerte & http://giselebundchen-online.com/ \\
\hline Paulo Coelho & $\begin{array}{l}\text { Político/ } \\
\text { Social }\end{array}$ & Paulo Coelho Institute & $\begin{array}{l}\text { Protesto contra o PT e } \\
\text { corrupção. }\end{array}$ & $\begin{array}{l}\text { http://paulocoelhoblog.com/ } \\
\text { http://pcfoundation.wpengine.com/ } \\
\text { foundation/index-paulo-coelho.php }\end{array}$ \\
\hline $\begin{array}{l}\text { Roberto } \\
\text { Carlos }\end{array}$ & Inerte & Instituto Amigo & Inerte & http://www.robertocarlos.com/br/home \\
\hline Cacá (Kaká) & Social & $\begin{array}{l}\text { Apoio a instituições } \\
\text { religiosas }\end{array}$ & Inerte & Inexiste \\
\hline $\begin{array}{l}\text { Luciano } \\
\text { Huck }\end{array}$ & Social & $\begin{array}{l}\text { Instituto Criar de TV, } \\
\text { Cinema e Novas } \\
\text { Mídias }\end{array}$ & $\begin{array}{l}\text { Engajamento na } \\
\text { campanha de Aécio } \\
\text { Neves }\end{array}$ & Inexiste \\
\hline $\begin{array}{l}\text { Luis Felipe } \\
\text { Scolari }\end{array}$ & Inerte & Inerte & Inerte & Inexiste \\
\hline
\end{tabular}

Quadro 4: O ativismo das celebridades brasileiras 
PROGRAMA DE PÓS-GRADUAÇÃO EM COMUNICAÇÃO DA UNIVERSIDADE FEDERAL DE SANTA MARIA

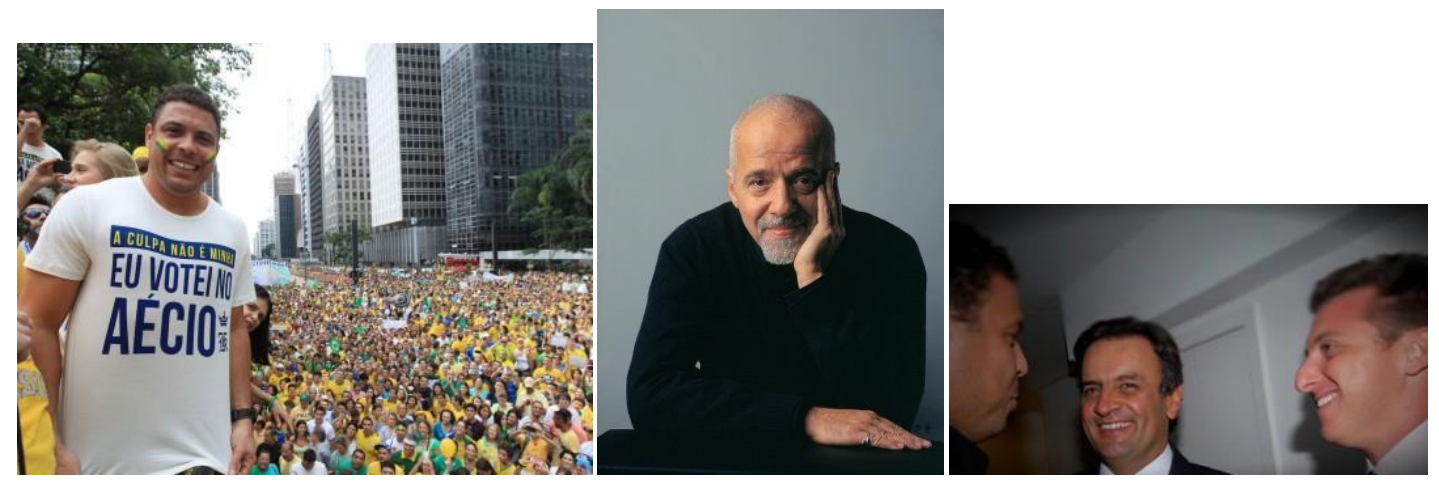

Ronaldo, Paulo Coelho e Luciano Huck apoiaram a oposição brasileira.

$\mathrm{Na}$ amostra brasileira das 10 celebridades mais influentes e poderosas seis estão relacionados ao futebol, uma é cantora, um é apresentador de TV, um é escritor e uma é modelo. Somente três entre eles mostram alguma relação com a temática política graças a suas declarações e seu envolvimento com a militância de grupos opositores no Brasil. Todos os demais evitam o envolvimento com esta temática. O ativismo social das celebridades brasileiras copia em boa medida o realizado pelos astros norte-americanos, muito embora não se equipare em volume e em intensidade às suas ações sociais. Em ambos os casos fica claro que em geral as celebridades do showbis e da mídia não são canais à comunicação dissidente.

Como exposto, é a crise social e política que oferece esta oportunidade. Nela, como se observou no Brasil em 1968, o discurso dissidente cresce e com o tempo torna-se consensual, diminuindo por consequência os riscos ao engajamento destes atores na militância. Cabe lembrar que o senso comum ocorre quando um dilema é resolvido e o impasse moral, social ou político que o gera é solucionado (Greene, 2013; p.307). Foi o que aconteceu também, em boa medida, no período da Guerra do Vietnã, oportunidade na qual a hostilidade das celebridades ao conflito contribuiu ao abalo da moral da população dos Estados Unidos.

Ou seja, acontece neste caso o que ocorre em qualquer rede social. Um personagem participará da dissidência se pelo menos certo número de membros de sua rede social se comprometer a também participar da ação coletiva. Quanto maior for o número de rebelados e maior for a manifestação dissidente maior será o safety net que protege as novas adesões (Wainberg, 2016B). No caso brasileiro recente, Lobão se destacou por quebrar o silêncio. Este primeiro passo é sempre o mais delicado, pois é voluntarioso.

Estudo de Thrall et all. (2008) mostra que, no caso americano, quanto mais poderosa a celebridade for mais ativa ela é. Em média, 90\% dos astros avaliados como poderosos mostram-se interessados em 4,16 temas (sociais e políticos) e estão envolvidos com 3,45 movimentos sociais. Este resultado é bem superior aos dados coletados por estes autores no 
PROGRAMA DE PÓS-GRADUAÇÃO EM COMUNICAÇÃO DA UNIVERSIDADE FEDERAL DE SANTA MARIA

grupo de estrelas com índice menor de poder. Neste caso 62,8\% dos personagens mostram-se interessados em 1,8 temas e estão envolvidos com 1,8 grupos de militantes. Portanto, a fama parece exercer um papel chave no ativismo estelar. $O$ estudo também ensina que ação militante é mais bem sucedida nos casos em que ela for capaz de agregar um número maior de celebridades envolvidas na causa. Um astro solitário não é capaz de produzir com seu ativismo o efeito publicitário desejado pelos ativistas. Outro resultado mostra que a mídia tradicional dá atenção ao ativismo estelar e que as celebridades tem sido úteis em especial na difusão de mensagens políticas de forma indireta, através do entretenimento (concertos pop, desenhos infantis, programas de televisão, por exemplo).

\section{CONCLUSÃO}

A descrição feita até aqui permite afirmar que (1) a dissidência radical é rara entre as celebridades da mídia e do showbis. (2) Os astros e as estrelas, sabendo que dependem da simpatia dos fãs para existirem como bem de consumo simbólico, evitam os temas polêmicos, os que dividem a opinião pública. (3) Ou seja, a celebridade é um ator social cauteloso. (4) Embora sempre exista uma audiência disposta a consumir mensagens rebeldes, de uma forma geral a ação social destas personalidades ocorre nos limites da esfera do consenso. O fato explica porque a celebridade está mais disposta ao ativismo social e menos ao ativismo político. (5) Embora a cooptação destas figuras pela autoridade seja mais comum nos regimes autoritários, ela é uma prática que ocorre também nas sociedades democráticas. (6) O caso da comunicação dissidente dos astros e das estrelas da mídia acontece em situações e nos contextos excepcionais de crise. (7) A comunicação dissidente quando realizada pelos astros através de seu ativismo político alcança sempre grande publicidade. (8) Aos olhos do público a radicalidade de um gesto simbólico da celebridade condensa valores caros de seus fãs. (9) Em geral, os fãs clubes das celebridades brasileiras são meros instrumentos de relações públicas destas personalidades do showbis e são utilizados para administrar e posicionar sua marca neste mercado (branding pessoal). (10) As celebridades operam de forma calculada, minimizando riscos, escolhendo a audiência, o tipo, o ambiente e o tempo de sua atuação pública, algo que é usualmente referido na obra sobre interacionismo simbólico como 'circunspecção dramatúrgica' (Goffman, 1996). (11) A nova realidade do mundo virtual permite que hoje em dia microcelebridades se convertam em personalidades da mídia massiva (macrocelebridades). (12) A celebridade é útil às manifestações cívicas e políticas pelas mesmas razões que explicam sua presença na publicidade comercial. Os astros influenciam a 
PROGRAMA DE PÓS-GRADUAÇÃO EM COMUNICAÇÃO DA UNIVERSIDADE FEDERAL DE SANTA MARIA

agenda da conversação social. Eles também causam o efeito priming ao estimularem certo tipo de resposta por parte do público (Kahneman, 2012; p. 52-58). Sem a presença dos astros e das estrelas nestas ocorrências a desatenção das massas permaneceria dispersa e disponível a outros atores que lutam entre si para conquista-la.

Por fim, há que se definir, o papel social da celebridade. Este conceito implica em tornar preciso o seu status social e o que esta posição autoriza este personagem realizar. Está claro que seu consumo pelas massas serve aos fins do escapismo coletivo. Mas não só. Em boa medida a celebridade é personalidade educadora, embora informal e por isso mesmo influente. Cabe recordar o ensinamento da falecida educadora americana Rita Pierson a respeito. Ela diz que as crianças aprendem de quem elas mais gostam. ${ }^{19}$ Esta regra serve aos seres humanos em geral. $\mathrm{O}$ culto do fã à personalidade mitificada do astro facilita a conexão e a interação entre os dois. A estrela tem a sua disposição um público devoto e infantilizado. As defesas psíquicas da audiência estão fragilizadas e a sua mente [porosa] está disponível à pura manipulação. A arte da retórica ensina que as virtudes do orador é fator determinante à persuasão e que o conteúdo do discurso chega à mente do receptor mais facilmente quando lubrificado pela emoção. (13) A aura que acompanha a celebridade lhe autoriza a desempenhar este papel educador também fora do palco. E quando o fazem, o fazem de forma cuidadosa, geralmente através de algum ato dramático e simbólico.

\section{REFERÊNCIAS}

BOORSTIN, Daniel. The Image: A Guide to Pseudo-Events in America. Vintage. 1992.

BROCKINGTON, D. 'Charities need to rethink celebrity' .Third Sector 8/11/2011. [http://www.thirdsector.co.uk/news/1102612/?DCMP=ILC-SEARCH].

COOPER, Andrew F. The sweep of celebrity activism.

[http://www.andrewfcooper.com/2010/12/17/the-sweep-of-celebrity-activism].

Celebrity Diplomacy. Paradigm Publishers. 2007.

DRIESSENS, Olivier. 'The celebritization of society and culture: Understanding the structural dynamics of celebrity culture.' International Journal of Cultural Studies. 16(6) 641-657, 2012 [Versão em português em http://www.uff.br/ciberlegenda/ojs/index.php/revista/article/view/808/395].

EARL, Jennifer \& Kimport, Katrina. 'Movement Societies and Digital Protest: Fan Activism and Other Nonpolitical Protest Online.' Sociological Theory, 27:3, 2009.

${ }^{19}$ Rita Pierson, TED Talk, Maio de 2013. 
EASTERLY, William. 'John Lennon vs. Bono: The death of the celebrity activist.' Washington Post. 10/12/2010.

GOFFMAN, Erving. A representação do eu na vida cotidiana. Petrópolis: Vozes, 1996.

GREENE, Joshua. Moral Tribes. Emotion, Reason and the Gap Between Us and Them. Penguin Books, 2013.

JAHNEMAN, Daniel. Thinking, Fast and Slow. Penguin Books. 2012.

KAPOOR, Ilan. Celebrity Humanitarism: The Ideology of Global Charity. Routledge, 2012.

KRAIDY, Marwan. 'The politics of revolutionary celebrity in the contemporary Arab world.' Public Culture. v. 27, n. 1 75:161-183, 2015.

MEYER, David S. \& Gamson, Joshua. 'The challenge of cultural elites: celebrities and social movements.' Sociological Inquiry. V.65, n2., p. 181-206, 1995.

MILNER Jr., Murray. 'Celebrity culture as a status system.' The Hedgehog Review. v.7, n.1, 2005.

MUNTEAN, Nick \& Pettersen, Anne Helen. 'Celebrity Twitter: Strategies of Intrusion and Disclosure in the Age of Technoculture'. M/C Journal, v. 12, n. 5. 2009.

MUKHERJEE J. “Celebrity, Media and Politics: An Indian Perspective.” Parliamentary Affairs 57:80-92. 2004.

THRALL, A. Trevor et al. 'Star Power: Celebrity advocacy and the Evolution of the Public Sphere.’ Press/Politics 13 (4): 362-385. 2008.

TSALIKI, Liza et al. (eds). Transnational Celebrity Activism in Global Politics: Changing the World? Intellect/University of Chicago, 2011.

TUFEKCI, Zeynep. 'Not this one: Social Movements, the Attention Economy, and Microcelebrity Networked Activism.' American Behavioral Scientist XX(X) 1-23, 2013.

WAINBERG, Jacques A. Línguas Ferinas. Um estudo sobre a polêmica e os polemistas. Edipucrs. 2010. ‘A Comunicação Dissidente e os Atos que Falam.’ 2016(a).

2016(b).

'As redes e os protestos sociais: a difusão da mensagem dissidente'. 
Original recebido em: 15/01/2016

Aceito para publicação em: 04/07/2016

Jacques Alkalai Wainberg

O autor é professor titular dos cursos de graduação e pós-graduação da Faculdade de Comunicação Social - Famecos, da Pontifícia Universidade Católica do Rio Grande do Sul. É doutor pela ECA/USP. Pesquisador CNPq 1C.

Esta obra está licenciada sob uma Licença Creative Commons. 